\title{
Effect of Drought Stress on Photosynthetic Parameters and Gene Expression in Brassica juncea L. (Czern. and Coss.)
}

\author{
Bharti Aneja ${ }^{1 *}$, Vishal Sharma ${ }^{2}$, Neelam R. $\operatorname{Yadav}^{1}, \operatorname{Ram}$ C. Yadav ${ }^{1}$ and S. S. Dudeja ${ }^{3}$ \\ ${ }^{1}$ Department of Molecular Biology, Biotechnology and Bioinformatics, Chaudhary Charan \\ Singh Haryana Agricultural University, Hisar, India \\ ${ }^{2}$ ICAR- National Bureau of Animal Genetic Resources, Karnal, India \\ ${ }^{3}$ Department of Microbiology, Chaudhary Charan Singh Haryana Agricultural University, \\ Hisar, India \\ *Corresponding author
}

\section{A B S T R A C T}

Keywords

Brassica juncea, Drought Stress, Photosynthetic Parameters

Article Info

\section{Accepted:}

07 January 2021

Available Online:

10 February 2021
Drought stress limits the plant growth resulting in drastic decline in the photosynthetic yield globally. The present investigation was carried out to study the expression of drought induced pp2c and lhcb genes in Brassica juncea cvs. RH0116 (drought tolerant) and RH8812 (drought sensitive) via semi-quantitative RT-PCR using actin as constitutive gene. Brassica plants were grown in net house and subjected to drought stress by withholding water at flowering stage. We observed that $\mathrm{pp} 2 \mathrm{c}$ gene was upregulated and was expressed in both shoots and roots during drought. The drought tolerant genotype exhibited higher accumulation of pp2c transcript than RH8812. However, lhcb gene was found to be down regulated during drought and its expression was present only in shoots. Seeds of both the genotypes were grown on MS medium with various levels of stress treatments using Mannitol and ABA. Seed germination was arrested at initial stage only and reduction in seed germination was significant among treatments and no seedling growth was observed in case of $\mathrm{ABA}$ treatment. Physiological parameters such as relative water content, osmotic potential, electrolyte leakage and chlorophyll fluorescence were also evaluated in stressed and control plants of both the genotypes and we found that physiological response was consistent with the changes in gene expression.

\section{Introduction}

Brassica juncea L. Czern \& Coss. (Indian mustard) is a crucifer, used as a source of food spice and folk medicine all over the world (Tian and Deng, 2020). It is the most widely cultivated oilseed crop in the Indian subcontinent (Akhtar et al., 2020), with very high acerage (6.9 million hectares) and production (7.2 million metric tonnes) (USDA, 2018-19). B. juncea also known as Oriental mustard, brown mustard, chinese mustard or leaf mustard is an annual herb (Lin et al., 2011) and is an allotetraploid (AABB, $2 \mathrm{n}=36$ ). It has evolved through multiple hybridization events between $B$. rapa (AA, 2n 
$=20)$ and B. nigra $(\mathrm{BB}, 2 \mathrm{n}=16)$ (Nagaharu, 1935).

Plants, being sedentary organisms are continuously challenged by a wide variety of abiotic stress such as drought, cold, high temperature, UV radiation, heavy metals and salinity hampering a lot quality and production of crops (Soda et al., 2015). Abiotic stresses are responsible for more than $50 \%$ decline in crop yield worldwide (Rodziewicz et al., 2014). Drought is a major abiotic stress which affects majority of the world's crop plants.

Drought tolerance in crops is a complex trait as it involves biochemical, physiological and morphological mechanisms (Kalina et al., 2016). Being a multigenic and quantitative trait, it is quite difficult to understand the molecular mechanism of abiotic stress tolerance. Also, there are hundreds of genes underlying the plant response to stress. In addition, drought cannot be forecast and hence plays a vital role in destabilizing the crop productivity (Amudha and Balasubramani, 2011). Plants have evolved acclimation and adaptation mechanisms to cope up with drought that includes avoidance, escape from stress and dehydration tolerance of the protoplast.

RH0116 is a drought tolerant variety of Brassica juncea, whereas RH8812 is drought sensitive, developed by CCS Haryana Agricultural University, Hisar (Aneja, 2014). RH0116 is also known to be tolerant to high temperatures (Sharma and Sardana, 2013). RH8812 was released in the year 1996, its average yield is $22 \mathrm{q} / \mathrm{ha}$, it gets matured at 142 days and possesses thick siliquae (www.hau.ernet.in). In this paper, we have discussed comparative study of these genotypes as they offer magnificent source to understand the mechanism of drought stress tolerance in Brassica juncea.
Photosynthesis is of central importance to plant growth and development and involves collection of light and transfer of solar energy to the reaction centers of PSII using LHC (light harvesting chlorophyll a/b- binding) proteins (Fanna et al., 2016). They are often associated with chlorophyll and xanthophyll and serve as antenna complex to drive photosynthetic electron transport ( $\mathrm{Gao}$ and $\mathrm{Li}$, 2015). LHC proteins are mostly found in thylakoids and encoded by nuclear genes (Kong et al., 2016).

PP2Cs or Protein phosphatase 2C play crucial role in plant processes such as cell differentiation, growth, metabolism, environmental stress signaling pathways and represent the major group of protein phosphatases in plants (Yang et al., 2018). These enzymes are monomeric with catalytic and regulatory domains present upon the same polypeptide. They need divalent metal ions such as $\mathrm{Mn}^{2+}$ or $\mathrm{Mg}^{2+}$ for their activity (Sugimoto et al., 2014). PP2Cs including PP2CA and ABI1/HAB1 branches are key negative regulators of ABA signaling (Zhang et al., 2013). Combined inactivation of specific PP2Cs involved in ABA signaling could provide an approach for improving crop performance under drought stress conditions (Rodriguez, 2006).

To have additional cognizance to the function of lhcb and $\mathrm{pp} 2 \mathrm{c}$ in drought tolerance, we examined their transcript levels in drought tolerant and sensitive cultivars of Brassica juncea. Development of PCR for detecting the presence of rare transcripts has revolutionized gene identification. Gene expression strategies such as semi-quantitative RT-PCR offers a sensitive, versatile and rapid method to analyse drought stress related gene expression. It requires gene specific primers for studying the differential gene expression (Chen et al., 2005). In this way, it can be useful for identification of certain key genes 
that play role in drought stress tolerance and overexpression of such genes can lead to increased productivity in case of drought (Aneja et al., 2015). In the present study, we also analyzed certain physiological parameters viz. seed germination studies, chlorophyll fluorescence, relative water content, osmotic potential and electrolyte leakage.

The dominant phase in the plant life cycle begins with seed germination (Yan et al., 2014) which proceeds by water uptake under favourable conditions leading to the activation of metabolic processes (Atia et al., 2011). ABA (Abscisic acid) hormone plays vital role in dormancy and germination control (Nambara et al., 2010). Drought stress induced by mannitol is also widely documented in many crop species (Ullah et al., 2014). Relative water content depicts absolute amount of water that a plant needs to attain saturation. Hence it is an important indicator of state of water balance of the plant (Arjenaki et al., 2012). Electrolytes such as $\mathrm{K}^{+}$, release outside the cell after a cell dies and loses membrane structural integrity. Hence electrolyte leakage can be used as a proxy for the extent of cell death (Hatsugai and Katagiri, 2018). Estimating the fluorescence emission from chlorophyll molecules of photosynthesizing plants is a commonly used non destructive technique involved in photosynthetic research. It is the most reliable test enabling the varietal discrimination as per their drought tolerance (Sayar et al., 2008).

\section{Materials and Methods}

\section{Plant material}

Indian mustard cultivars (RH8812 and RH0116) seeds were procured from Department of Genetics and Plant Breeding, CCSHAU, Hisar.

\section{In vivo drought stress treatment}

Plants (RH0116 and RH8812) were seeded and grown in pots in nethouse. Plants were regularly watered with equal amounts of water (to keep the water level equal) and Hoagland Solution (50 $\mathrm{ml}$ each) to supply them adequate amounts of nutrients for growth. At the stage of flowering, one half of the plants of both the genotypes was segregated as control (in which watering was continued) and the second set of plants was subjected to drought stress condition by withholding watering.

Samples of shoot and root tissues were taken from the control and stressed plants and were stored at $-80^{\circ} \mathrm{C}$ for RNA isolation and for analyzing the physiological parameters such as relative water content, osmotic potential and electrolyte leakage.

Post sampling, the drought stressed plants were rehydrated by equal amounts of water. The day wilting disappeared samples were taken again for analysis.

\section{Germination studies in Indian mustard under drought stress condition}

Seeds of both the cultivars (RH0116 and RH8812) were grown on MS medium having varying levels of stress treatments using mannitol $(100 \mu \mathrm{M}, \quad 200 \mu \mathrm{M}, \quad 300 \mu \mathrm{M}$ and $400 \mu \mathrm{M})$ and ABA $(10,50$ and $100 \mu \mathrm{M})$. Physiological attributes like seed germination pattern, shoot and root lengths were estimated after 2 weeks.

\section{Physiological studies}

The control, stressed and rehydrated Brassica plants were grown in nethouse and the following physiological parameters were studied: 


\section{Relative water content}

For the estimation of RWC, two fully expanded leaves (of in vivo grown plants of each variety RH8812 and RH0116) were cut into tiny pieces and weighed to record the fresh weight (Yamasaki and Dillenburg, 1999).

The leaf samples were then hydrated till they became fully turgid by immersing in deionized water in a closed petriplate for $4 \mathrm{hrs}$. Thereafter the samples were removed from water and any surface moisture was soaked using filter paper and immediately weighed to record full turgid weight.

Then the samples were oven- dried at $70^{\circ} \mathrm{C}$ for $24 \mathrm{hrs}$ and weighed to record the dry weight of the sample. The experiment was performed in triplicates and RWC was estimated using following formula

$$
\text { RWC }(\%)=100 \times \frac{\text { Fresh weight-Dry weight }}{\text { Turgid weight-Dry weight }}
$$

\section{Osmotic potential}

Osmotic potential of leaf was estimated using Vapour pressure osmometer (Wescor INC., USA). The leaves were excised from control, stressed and rehydrated plants and were sealed in syringes separately and immediately frozen at $-20^{\circ} \mathrm{C}$. The samples were thawed for $60 \mathrm{~min}$ at $25^{\circ} \mathrm{C}$ prior to the measurement of osmotic potential.

Then the sap was released from the syringe. A filter paper disc was immersed in the sap and quickly placed inside the vapour pressure osmometer chamber.

The chamber was sealed and the osmotic potential values were recorded. For calibrating the osmometer, standard solutions of $\mathrm{NaCl}(0.1 \mathrm{mM}-1.0 \mathrm{M})$ were used.

\section{Electrolyte leakage}

The relative integrity of plasma memberane was determined as the Percentage Electrolyte leakage (Gong et al., 1998). Fresh leaves were excised into small pieces and put in test tubes.

The test tubes were incubated at $52^{\circ} \mathrm{C}$ for $1 \mathrm{hr}$ in a water bath and $10 \mathrm{ml}$ of deionised water was added to it and kept overnight.

The initial electrical conductivity (EC1) was estimated on the next day. Thereafter the samples were autoclaved to release all the electrolytes, cooled and then, the final electrical conductivity (EC2) was estimated. The leakage percentage of electrolytes was calculated as (1-EC1/EC2) X 100.

\section{RNA Isolation and cDNA synthesis}

Total RNA was isolated from the control, stressed and rehydrated plant samples (shoot and root tissues) by means of Trizol method (Chomczynski, 1993) with some modifications as described in Aneja et al., (2015).

The RNA samples were reverse transcribed by using oligo dT primer $(0.5 \mu \mathrm{g})$, total RNA (1 $\mu \mathrm{g})$, dNTPs mix $(4 \mathrm{mM})$, reverse transcriptase enzyme (200 units) and RNase inhibitor (20 U).

\section{Semi- quantitative RT-PCR}

For gene expression analysis, the primers for pp2c and lhcb genes were synthesized by using sequences from Arabidopsis (Zhang et $a l ., 2008)$. The primers used for PCR analysis are given in table 1 . 


\begin{tabular}{|l|l|l|c|}
\hline Gene & Forward Primer & Reverse Primer & $\begin{array}{c}\text { Annealing } \\
\text { temperature } \\
\text { ('C) }\end{array}$ \\
\hline $\boldsymbol{p p} \mathbf{2 c}$ & $\begin{array}{l}\text { 5'CAAATGGCTGGGATTT } \\
\text { GTTGC 3' }\end{array}$ & $\begin{array}{l}\text { 5'AAGACGACGCTTGATTATT } \\
\text { CCTC 3' }\end{array}$ & 51.0 \\
\hline $\boldsymbol{l h c \boldsymbol { b }}$ & $\begin{array}{l}\text { 5'CAACGATCTCCTCCGC } \\
\text { AAA3' }\end{array}$ & $\begin{array}{l}\text { 5'CTTGACGGTACGACGCATG } \\
\text { AT3' }\end{array}$ & 50.5 \\
\hline $\boldsymbol{B j}$ Actin & $\begin{array}{l}\text { 5'TGGCATCACACTTTCTA } \\
\text { CAA3' }\end{array}$ & $\begin{array}{l}\text { 5'CAACGGAATCTCTCAGCTC } \\
\text { C3' }\end{array}$ & 54.3 \\
\hline
\end{tabular}

PCR reaction was performed in a $20 \mu \mathrm{l}$ reaction volume containing $10 \mathrm{X}$ PCR buffer (containing $2.5 \mathrm{mM} \mathrm{MgCl}$ ), $200 \mu \mathrm{M}$ of dNTPs, $0.6 \mu \mathrm{M}$ of primers (forward and reverse), $1 \mathrm{U}$ Taq DNA Polymerase and template (cDNA- 20 ng). PCR cycling conditions consisted of an initial denaturation at $94^{\circ} \mathrm{C}$ for $2 \mathrm{~min} ; 36$ cycles of $92^{\circ} \mathrm{C}$ for 1 min; annealing for $30 \mathrm{sec}$ and $72^{\circ} \mathrm{C}$ for $1 \mathrm{~min}$; and a final extension at $72^{\circ} \mathrm{C}$ for $10 \mathrm{~min}$.

\section{Germination studies in Brassica juncea} under drought stress

Seeds of Brassica juncea cvs. RH0116 and RH8812 were grown on MS medium with varying levels of stress treatments using $\mathrm{ABA}$ $(10 \mu \mathrm{M}, \quad 50 \mu \mathrm{M}, \quad 100 \mu \mathrm{M})$ and Mannitol $(100 \mu \mathrm{M}, \quad 200 \mu \mathrm{M}, \quad 300 \mu \mathrm{M}, \quad 400 \mu \mathrm{M})$. Physiological attributes such as seed germination, shoot and root length were recorded after 2 weeks.

\section{Results and Discussion}

Analysis of lhcb and pp2c gene expression in Brassica juncea cvs. RH8812 and RH0116 under drought stress condition

The transcripts of lhcb were expressed only in the shoots and not in roots (Fig. 1) while pp2c gene transcript was present in both roots and shoots (Fig. 2). The expression of lhcb gene was down regulated while that of $\mathrm{pp} 2 \mathrm{c}$ gene was upregulated in the plants exposed to drought stress conditions. The transcripts of lhcb gene were absent in the drought stressed plants and present in the control and rehydrated plants. The transcripts of $\mathrm{pp} 2 \mathrm{c}$ gene were expressed only in the drought stressed plants and the expression level was higher in the drought tolerant genotype vs drought sensitive genotype. Housekeeping gene actin was expressed in the roots and shoots of all the plant groups viz. control, drought stressed and rehydrated plants (Fig. $3)$.

\section{Physiological Studies}

Seed germination under drought stress condition induced by mannitol and abscisic acid (ABA)

The percent seed germination and the average length of root and shoot decreased as the concentration of mannitol was increased 100 $\mu \mathrm{M}, 200 \mu \mathrm{M}, 300 \mu \mathrm{M}$ and $400 \mu \mathrm{M}$ (Table 1 and Fig. 4-6). The average root and shoot length was minimum at $400 \mu \mathrm{M}$ and highest in control. The root/shoot ratio in the mannitol- stressed seedling was lesser as compared to the control, however, the root/shoot ratio increased with the concentration of mannitol (Fig. 7). Root/shoot ratio of the tolerant genotype, RH0116, was always higher than the sensitive genotype, RH8812 at the respective concentration of mannitol. The shoot length in RH0116 and RH8812 decreased by $4.21 \%$, and $4.48 \%$ at 100 and $200 \mu \mathrm{M}$ mannitol, respectively and the respective decrease at 300 and $400 \mu \mathrm{M}$ was $16.45 \%$ and $16.41 \%$. Similarly, the root length in RH0116 and RH8812 decreased by 
$14.54 \%$ and $10.50 \%$ at 100 and $200 \mu \mathrm{M}$ mannitol, respectively and the respective decrease at 300 and $400 \mu \mathrm{M}$ was $26.06 \%$ and $22.50 \%$.

Seed germination was observed in both RH0116 and RH8812 in drought stress condition induced by ABA at concentration of $10 \mu \mathrm{M}, 50 \mu \mathrm{M}$ and $100 \mu \mathrm{M}$ in MS media. In RH0116 and RH8812, the seed germination was highest in the control (MS media without ABA) (93.33\% vs $60.00 \%)$ and least at 100 $\mu \mathrm{M}$ ABA (50.00\% vs $33.30 \%)$. However, no seedling growth was observed in the seeds germinated in the drought stress induced by ABA at any concentration (Fig. 8-11, Table 1)

\section{Physiological parameters in Brassica juncea (cvs. RH8812 and RH0116) under drought stress}

The physiological parameters such as Relative water content, Osmotic potential, Electrolyte leakage and Chlorophyll fluorescence were observed in the in vivo grown stressed, control and rehydrated groups of Brassica plants, and two weeks old Brassica juncea (cvs. RH8812 and RH0116) seedlings (grown in vitro) subjected to air drying stress (for 15 min, $30 \mathrm{~min}, 1 \mathrm{hr}$ and $2 \mathrm{hr}$ ).

\section{Chlorophyll fluorescence in Brassica juncea (cvs. RH8812 and RH0116) under drought stress}

With the help of PEA analyzer, chlorophyll fluorescence was observed was observed in the Brassica juncea (cvs. RH8812 and RH0116) plants under drought stress conditions in the plants grown in in vivo conditions and in in vitro grown seedlings. The ratio of minimum fluorescence to maximum fluorescence ( $\mathrm{Fo} / \mathrm{Fm})$ was higher in the stressed plants as compared to control plants in both the conditions (in vivo and in vitro). In the rehydrated and control plants of both the genotypes (sensitive as well as tolerant), similar kind of observation was seen. While the ratio of variable fluorescence to maximum fluorescence $(\mathrm{Fv} / \mathrm{Fm})$ was higher in the control as compared to stressed plants of both the genotypes. However, the increase was more in the RH8812 (drought sensitive) genotype; and almost same in the rehydrated and control plants in both the genotypes (Table 2). In the in vitro grown seedlings, the increase in the $\mathrm{Fo} / \mathrm{Fm}$ ratio and decrease in the $\mathrm{Fv} / \mathrm{Fm}$ ratio was observed with the increased duration of the stress (from $15 \mathrm{~min}$ to $2 \mathrm{hr}$ ) in both the cultivars of Brassica juncea (Table 3).

\section{Relative Water Content in Brassica juncea (cvs. RH8812 and RH0116) under drought stress}

Relative water content $(\%)$ in the in vitro grown seedlings of Brassica juncea, decreased as the duration of drought stress (15 min, $30 \mathrm{~min}, 1 \mathrm{hr}$ and $2 \mathrm{hr}$ ), induced by air drying, increased. RWC (\%) was highest in the control plants and minimum in the plants exposed to stress for two hr, in both the cultivars (Fig. 12). The decrease in the RWC (\%) was more for the drought sensitive variety, RH8812 (from $84.55 \%$ to $33.85 \%$ ), as compared to the drought tolerant variety, RH0116 (from $79.10 \%$ to $39.55 \%$ ).

\section{Osmotic potential and Electrolyte leakage in Brassica juncea (RH8812 and RH0116) under drought stress}

As the duration of stress was increased (15 min, $30 \mathrm{~min}, 1 \mathrm{hr}$ and $2 \mathrm{hr}$ ), decrease in osmotic potential was observed in the in vitro grown seedlings (Fig. 13). Maximum decrease in osmotic potential was observed at 2 hours of drought treatment i.e. $-1.37 \mathrm{MPa}$ in RH8812 and -1.35 MPa in RH0116. Similarly, the electrolyte leakage percentage in the in vitro grown plants also increased as 
the duration of drought stress, induced by air drying, was increased (15 min, $30 \mathrm{~min}, 1 \mathrm{hr}$ and $2 \mathrm{hr}$ ), in both the genotypes. Maximum electrolyte leakage was observed after the stress of $2 \mathrm{hr}$ of stress treatment, as the electrolyte leakage $(\%)$ increased from $15 \%$ to $30 \%$ in $\mathrm{RH} 0116$ and from $17 \%$ to $38 \%$ in RH8812 as compared to control (Fig. 14).

Table.1 Seed germination (\%age) in B. juncea (cvs. RH0116 and RH8812) under drought stress induced by Mannitol and abscisic acid (ABA)

\begin{tabular}{|l|l|l|l|}
\hline \multicolumn{2}{|c|}{} & \multicolumn{2}{|l|}{ Per cent germination } \\
\hline Treatment & RH0116 & RH8812 \\
\hline Mannitol & Control & $83.33 \%$ & $\mathbf{8 0 . 0 0 \%}$ \\
\cline { 2 - 4 } & $100 \mu \mathrm{M}$ Mannitol & $80.00 \%$ & $\mathbf{5 6 . 6 6 \%}$ \\
\cline { 2 - 4 } & $200 \mu \mathrm{M}$ Mannitol & $63.33 \%$ & $\mathbf{5 3 . 3 3 \%}$ \\
\cline { 2 - 3 } & $300 \mu \mathrm{M}$ Mannitol & $70.00 \%$ & $\mathbf{4 6 . 6 6 \%}$ \\
\hline ABA & $400 \mu \mathrm{M}$ Mannitol & $60.00 \%$ & $\mathbf{4 0 . 0 0 \%}$ \\
\hline & Control & $93.33 \%$ & $\mathbf{6 0 . 0 0 \%}$ \\
\hline & $10 \mu \mathrm{M}$ ABA & $73.00 \%$ & $\mathbf{4 0 . 0 0 \%}$ \\
\hline & $50 \mu \mathrm{M} \mathrm{ABA}$ & $66.00 \%$ & $\mathbf{4 0 . 0 0 \%}$ \\
\hline & $\mathbf{1 0 0} \boldsymbol{\mu M}$ ABA & $\mathbf{5 0 . 0 0 \%}$ & $\mathbf{3 3 . 3 0 \%}$ \\
\hline
\end{tabular}

Table.2 Chlorophyll fluorescence in the Brassica juncea plants (RH8812 and RH0116) in in vivo conditions

\begin{tabular}{|c|c|c|c|c|c|c|c|c|}
\hline & $\begin{array}{c}\text { RH8812 } \\
\text { Stressed }\end{array}$ & $\begin{array}{c}\text { RH8812 } \\
\text { Control }\end{array}$ & $\begin{array}{c}\text { RH0116 } \\
\text { Stressed }\end{array}$ & $\begin{array}{c}\text { RH0116 } \\
\text { Control }\end{array}$ & $\begin{array}{c}\text { RH8812 } \\
\text { Rehydrated }\end{array}$ & $\begin{array}{c}\text { RH8812 } \\
\text { Control }\end{array}$ & $\begin{array}{c}\text { RH0116 } \\
\text { Rehydrated }\end{array}$ & $\begin{array}{c}\text { RH0116 } \\
\text { Control }\end{array}$ \\
\hline $\mathrm{F}_{0} / \mathrm{F}_{\mathrm{m}}$ & 0.32 & 0.29 & 0.32 & 0.28 & 0.28 & 0.29 & 0.30 & 0.30 \\
\hline $\mathrm{F}_{\mathrm{v}} / \mathrm{F}_{\mathrm{o}}$ & 1.70 & 2.33 & 1.82 & 2.55 & 2.32 & 2.34 & 2.31 & 2.30 \\
\hline $\mathrm{Fv} / \mathrm{Fm}$ & 0.54 & 0.67 & 0.58 & 0.71 & 0.65 & 0.68 & 0.69 & 0.69 \\
\hline
\end{tabular}

(where, $\mathrm{F}_{\mathrm{o}}=$ minimum fluorescence, $\mathrm{F}_{\mathrm{m}}=$ maximum fluorescence, $\mathrm{F}_{\mathrm{v}}=$ variable fluorescence)

Table.3 Chlorophyll fluorescence in the Brassica juncea plants (RH8812 and RH0116) in in vitro conditions

\begin{tabular}{|l|c|c|c|c|c|c|}
\hline & \multicolumn{3}{|c|}{ RH8812 } & \multicolumn{3}{c|}{ RHo116 } \\
\hline & Fo/Fm & Fv/Fo & Fv/Fm & Fo/Fm & Fv/Fo & Fv/Fm \\
\hline Control & 0.35 & 1.88 & 0.66 & 0.41 & 1.45 & 0.59 \\
\hline Stressed (15 min) & 0.65 & 0.53 & 0.34 & 0.67 & 0.50 & 0.34 \\
\hline Stressed (30 min) & 0.78 & 0.28 & 0.22 & 0.76 & 0.32 & 0.24 \\
\hline Stressed (1 hr) & 0.85 & 0.18 & 0.15 & 0.89 & 0.12 & 0.20 \\
\hline Stressed (2 hr) & 0.91 & 0.10 & 0.09 & 0.93 & 0.19 \\
\hline Rehydrated (15 min) & 0.75 & 0.32 & 0.24 & 0.77 & 0.29 & 0.22 \\
\hline Rehydrated (30 min) & 0.75 & 0.33 & 0.25 & 0.73 & 0.36 & 0.26 \\
\hline Rehydrated (1 hr) & 0.74 & 0.34 & 0.25 & 0.67 & 0.49 & 0.33 \\
\hline Rehydrated (2 hr) & 0.75 & 0.32 & 0.24 & 0.76 & 0.30 \\
\hline
\end{tabular}

(where, $\mathrm{F}_{\mathrm{o}}=$ minimum fluorescence, $\mathrm{F}_{\mathrm{m}}=$ maximum fluorescence, $\mathrm{F}_{\mathrm{v}}=$ variable fluorescence) 
Fig.1 Agarose gel electrophoresis of $l h c b$ transcripts in Brassica juncea genotypes under drought stress

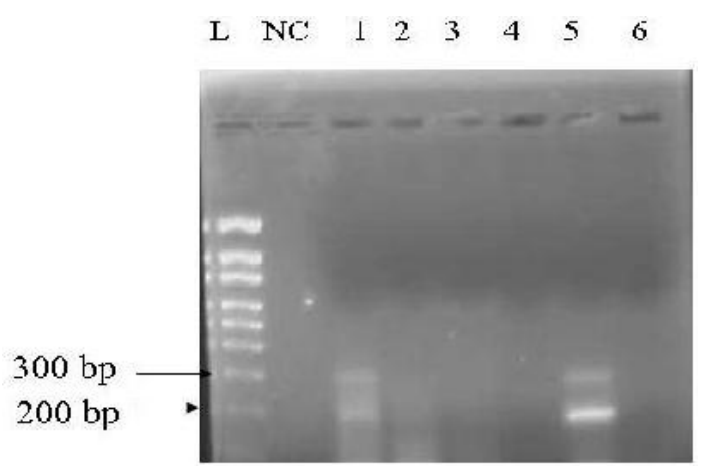

Lane L-Ladder; NC-Negative control; 1-RH0116 control; 2-RH0116 root; 3-RH8812 root; 4RH0116 stressed; 5-RH8812 control; and 6-RH8812 stressed

Fig.2 Agarose gel electrophoresis of $p p 2 c$ transcripts in Brassica juncea genotypes under drought Stress

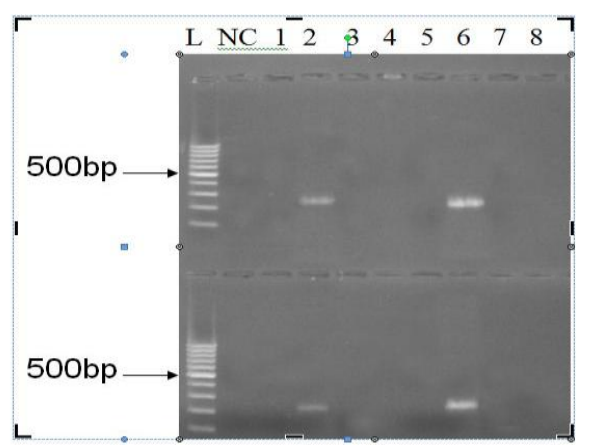

Lane L-Ladder; NC-Negative control (NC); 2-RH8812 control (shoot); 3-RH8812 stressed (shoot); 4-RH8812 rehydrated (shoot); 6-RH0116 control (shoot); 7-RH0116 stressed (shoot); 8-RH0116 rehydrated (shoot); 11RH8812 control (root); 12-RH8812 stressed (root); 13-RH8812 rehydrated (root); 15-RH0116 control (root); 16RH0116 stressed (root); 17-RH0116 rehydrated (root).

Fig.3 Agarose gel electrophoresis of actin transcripts in Brassica juncea genotypes under drought stress

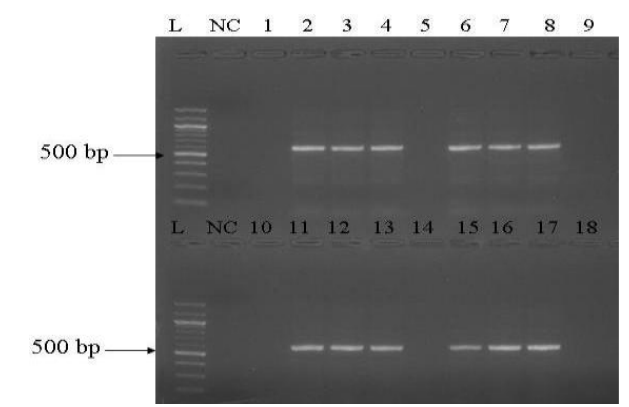

Lane L-Ladder; NC-Negative control (NC); 2-RH8812 control (shoot); 3-RH8812 stressed (shoot); 4-RH8812 rehydrated (shoot); 6-RH0116 control (shoot); 7-RH0116 stressed (shoot); 8-RH0116 rehydrated (shoot); 11RH8812 control (root); 12-RH8812 stressed (root); 13-RH8812 rehydrated (root); 15-RH0116 control (root); 16RH0116 stressed (root); 17-RH0116 rehydrated (root) 
Fig.4 In vitro seed germination response in Brassica juncea cvs. RH0116 and RH8812 subjected to various levels of mannitol treatment $(\mathrm{a}=$ mannitol $0 \%$ i.e. control, $\mathrm{b}=$ mannitol $100 \mu \mathrm{M}, \mathrm{c}=$ mannitol $200 \mu \mathrm{M}, \mathrm{d}=$ mannitol $300 \mu \mathrm{M}$, mannitol $400 \mu \mathrm{M}$ )
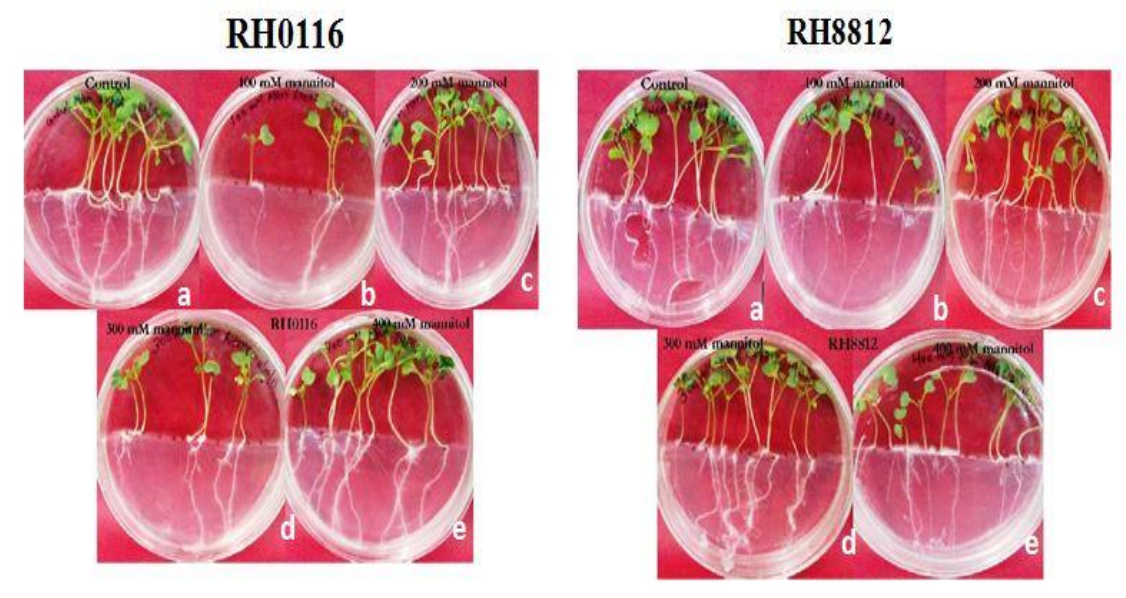

Fig.5 Shoot length in the germinated seedlings of $B$. juncea (cvs. RH0116 and RH8812) under drought stress induced by different concentrations of mannitol $(100,200,300 \& 400 \mu \mathrm{M})$

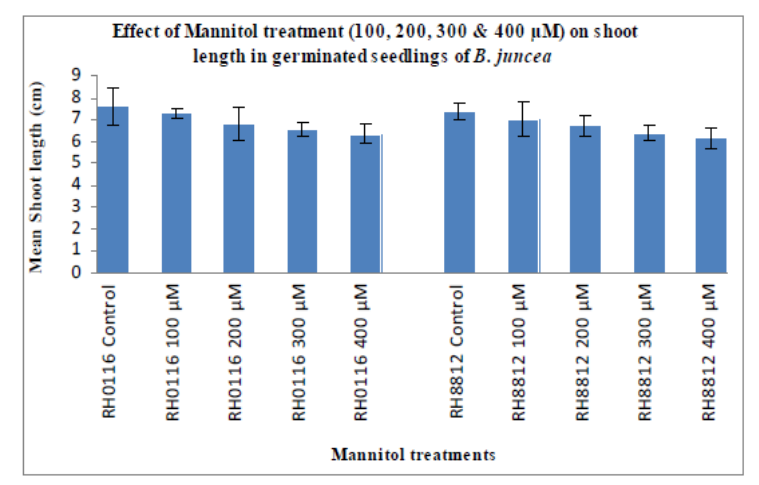

Fig.6 Root length in the germinated seedlings of B. juncea (cvs. RH0116 and RH8812) under drought stress induced by different concentrations of mannitol $(100,200,300 \& 400 \mu \mathrm{M})$

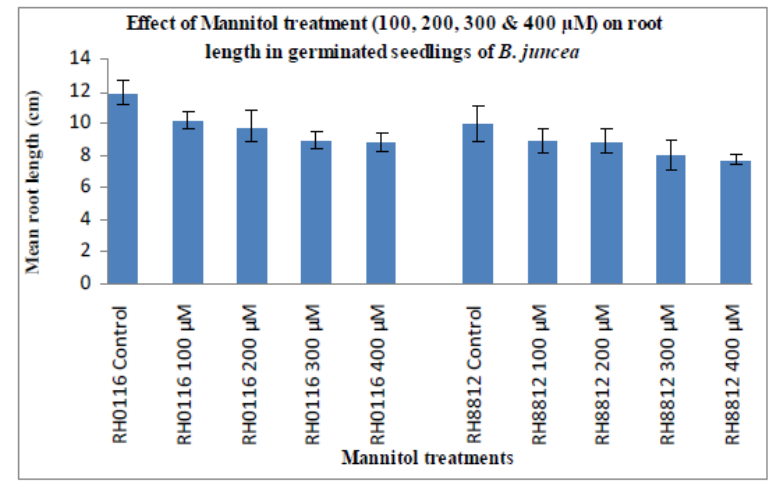


Fig.7 Root:Shoot ratio in the germinated seedlings of B. juncea (cvs. RH0116 and RH8812) under stress induced by mannitol treatment $(100,200,300 \& 400 \mu \mathrm{M})$

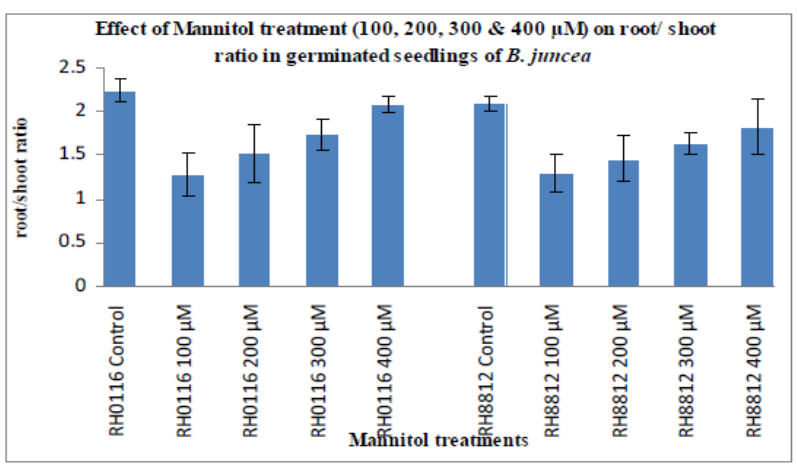

Fig.8 In vitro seed germination response in Brassica juncea cvs. RH0116 and RH8812 subjected to various levels of ABA treatment ( $\mathrm{a}=\mathrm{ABA} 0 \%$ i.e. control, $\mathrm{b}=\mathrm{ABA} 10 \mu \mathrm{M}, \mathrm{c}=\mathrm{ABA} 50 \mu \mathrm{M}$, $\mathrm{d}=\mathrm{ABA} 100 \mu \mathrm{M})$

RH0116

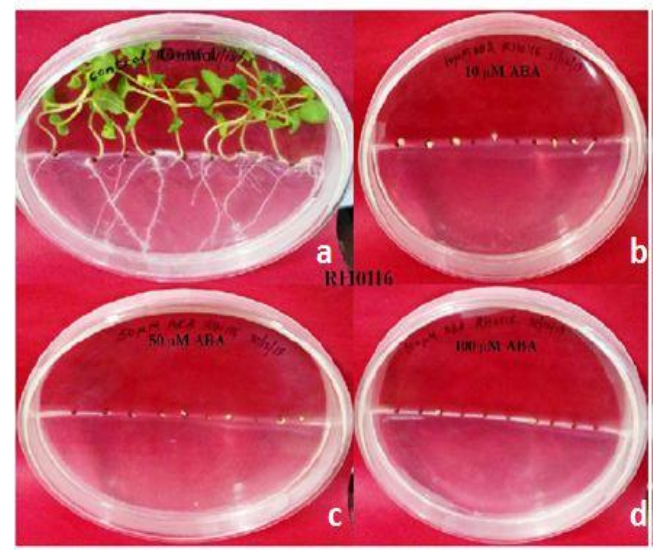

RH8812

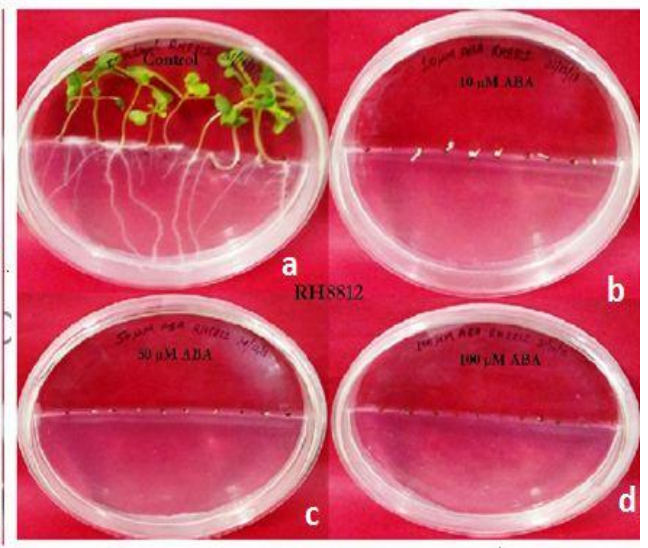

Fig.9 Shoot length in the germinated seedlings of B. juncea (cvs. RH0116 and RH8812) under drought stress induced by different concentrations of absicic acid (ABA)

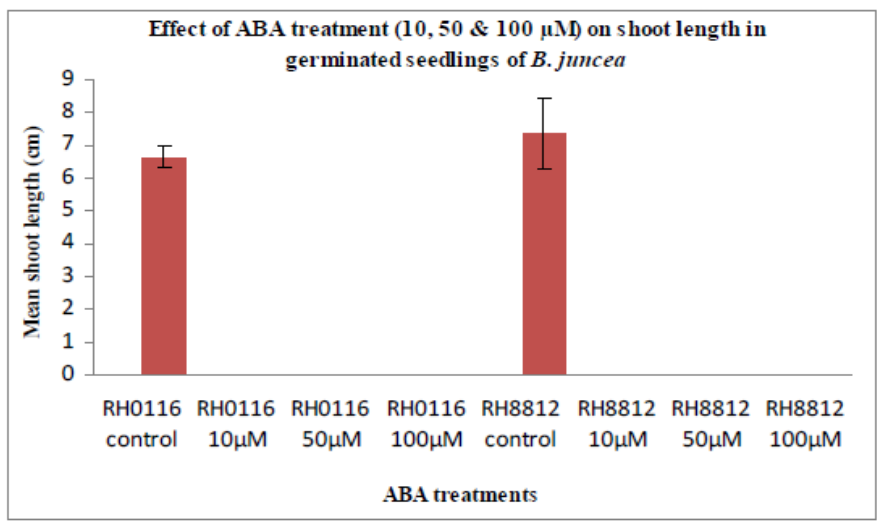


Fig.10 Root length in the germinated seedlings of B. juncea (cvs. RH0116 and RH8812) under drought stress induced by different concentrations of absicic acid (ABA)



Fig.11 Root:Shoot ratio in the germinated seedlings of B. juncea under stress induced by abscisic acid (ABA) treatment $(10,50 \& 100 \mu \mathrm{M})$

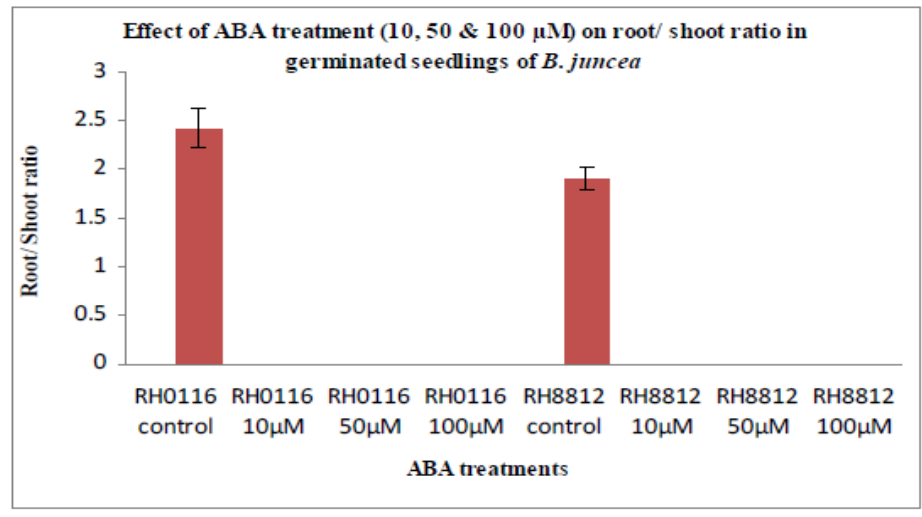

Fig.12 Relative water content (\%) under in vitro drought stress condition in Brassica juncea plants

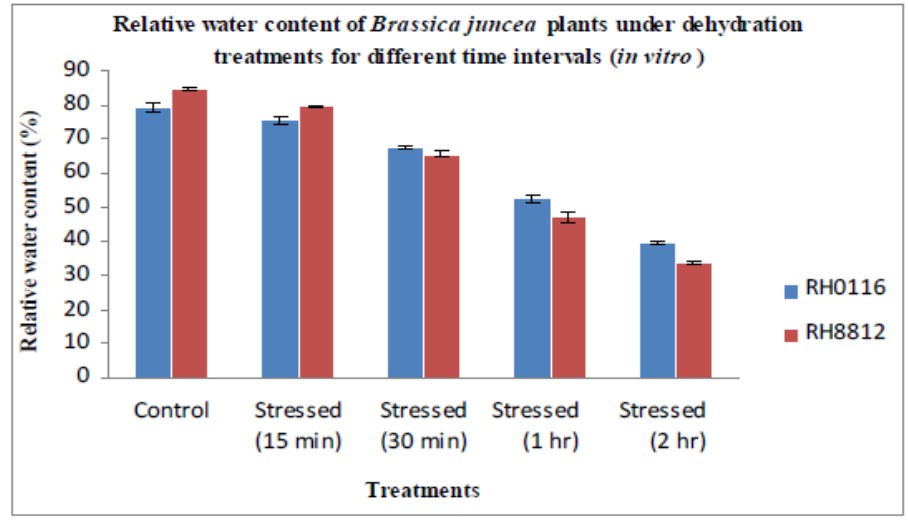


Fig.13 Osmotic potential under in vitro drought stress condition in Brassica juncea plants

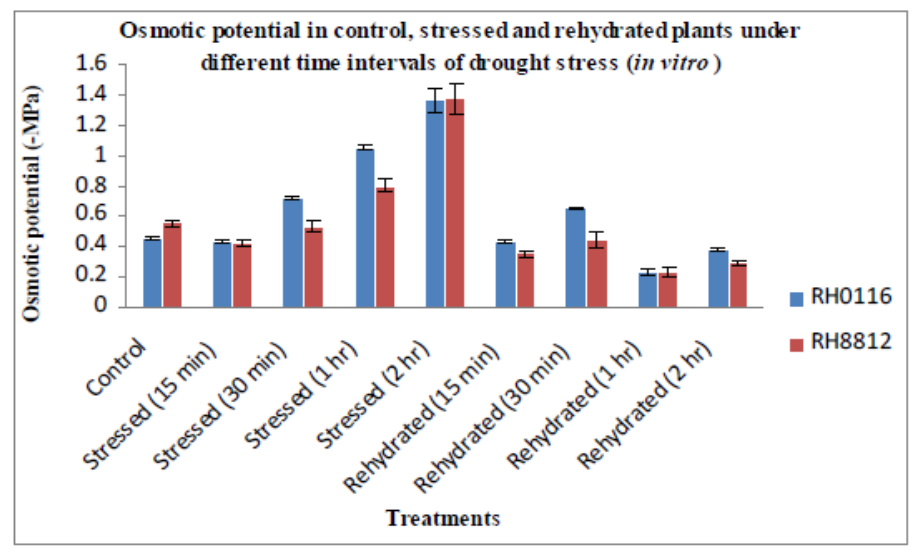

Fig.14 Electrolyte leakage under in vitro drought stress condition in Brassica juncea plants

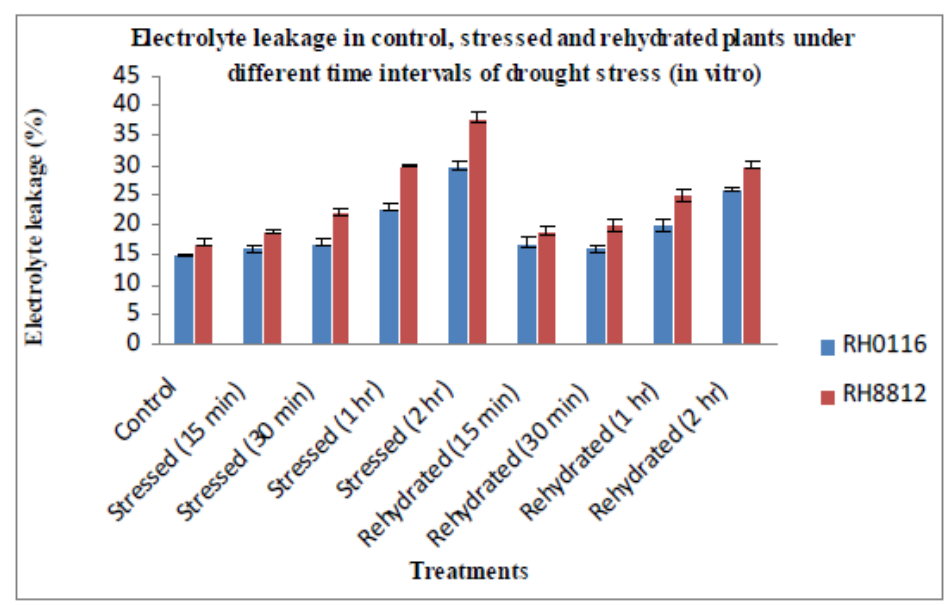

Water is a critical resource for plant growth and development and its associated physiological phenomenon and due to its limited supply in arid and semi-arid ecosystems, plants have to suffer water deficit which further hampers photosynthesis and net productivity of plants in arid ecosystems (Luo et al., 2014). Also it is foreseen that as a result of global warming, plants would be exposed to such stresses in near future (IPCC, 2007). Having crops with better WUE (water use efficiency), achieved via genetic engineering or breeding technologies is the most reliable solution to the problem of water scarcity (Chaerle et al., 2005).
Analysis of physiological parameters in Brassica juncea under drought stress

Physiological and biochemical modifications due to abiotic stress in plants are related to altered expression of genes (Saibo et al., 2009) and affected by the intensity, duration and rate of progression of the stress imposed (Chaves et al., 2009). However, a particular stage e.g. germination, seedling or flowering could be the most critical one for drought stress depending upon the species. Also studies have proven that in specific genotypes, drought induced gene expression was in consistence with the physiological response (Hazen et al., 2005; Street et al., 
2006). Uptake of water after the seed dormancy is broken paves the way for germination to occur (Atia et al., 2011), which further initiates the dominant phase of life cycle of higher plants (Yan et al., 2014).

Mannitol (or manna sugar) with the chemical formula $\mathrm{C}_{6} \mathrm{H}_{8}(\mathrm{OH})_{6}$, is a sugar alcohol and is white, crystalline solid. It controls the osmotic potential in culture media so as to induce drought (Nilanthi et al., 2015). Abscisic acid (ABA) is a hormone which plays an important role in dormancy as well as controls germination (Nambara et al., 2010).

In the present study, we have recorded seed germination, shoot and root length 2 weeks post drought stress treatment by using Mannitol (100, 200, 300, $400 \mu \mathrm{M})$ and ABA $(10,50,100 \mu \mathrm{M})$ under in vitro condition. It was observed that seed germination was arrested at the initial stage and reduction in seed germination was significant among mannitol treatment. There was differential seed germination in case of ABA treatment, however, no seedling growth was observed in case of ABA treatment. Bibi et al., (2010) reported in sorghum that physiological and morphological parameters are affected by drought stress. Okcu et al., (2005) observed that drought stress resulted in shorter shoots and in some cases, longer roots. Also, a longer root is characteristic feature of drought tolerant variety. In our study also we found that the average shoot and root lengths of the in vitro grown seedlings after mannitol treatment decreased with increased dose of mannitol in both the genotypes, however more reduction was recorded in RH8812 when $400 \mu \mathrm{M}$ mannitol was used.

Since plant growth is directly linked with its RWC, changes in the water status of plant due to drought also needs to be focused upon (Hayatu et al., 2014). RWC (relative water content) and leaf water potential are important parameters for studying physiological response of plant in case of drought (Marchese et al., 2010; Silva et al., 2010). Medeiros et al., (2012) stated that these parameters decrease in most plants under drought stress. Arjenaki et al., (2012) studied the effect of drought on chlorophyll content, RWC (relative water content) and mineral elements in wheat. It was observed that chlorophyll content, RWC and ion concentration of $\mathrm{K}$ and $\mathrm{Na}$ were varying among resistant and sensitive genotypes. Similarly we also found rapid decline in RWC when Brassica plants were subjected to water stress. The decline was greater in sensitive check as compared to RH0116. Also RH0116 (tolerant) exhibited higher recovery of RWC upon rehydration of stressed plants. In vitro studies also reflect similar kind of response (Personal data). Kumar et al., (2013) characterized temperature tolerant Brassica genotypes on the basis of RWC and they observed that late sown Brassica showed higher decline in RWC than the early sown. In Plantago, RWC showed sharp decrease upon intensifying stress (Rahimi et al., 2010). Saura-Mas and Lloret (2007) also found similar observations in case of woody species. It clearly supports our results as increasing the duration of air drying from $15 \mathrm{~min}$ to $2 \mathrm{~h}$ in Brassica seedlings decreased the RWC progressively (Personal data).

Our results also reveal that the values of osmotic potential were more negative in case of drought subjected plants than control plants. Also as the duration of drought stress treatment increased, the seedlings showed more negative osmotic potential. The decline was higher in sensitive variety than tolerant. Alikhan et al., (2010) also reported reduced relative water contents, osmotic potential under water stress in rapeseed.

Brassica juncea seedlings were evaluated for heat stress tolerance by Wilson et al., (2014). 
They observed that electrolyte leakage was more in susceptible genotypes as compared to the tolerant ones. Similarly we also found that electrolyte leakage was increased when the plants were subjected to drought stress as compared to control plants and the increase was relatively more in sensitive variety (RH8812) as compared to the tolerant variety (RH0116). Sayar et al., (2008) also reported that leakage was found to be significantly more in sensitive varieties and the values increased as the dehydration time increased. We also observed progressive increase in the values of electrolyte leakage with increased drought stress treatment. This suggests that electrolyte leakage parameter is an indicator for assessment of drought, heat or cold stress in crop plants.

Chlorophyll fluorescence technique has helped in understanding photochemical and non photochemical processes occurring in thylakoid membrane of chloroplast. It provides useful information about leaf photosynthetic performance of many plants under drought stress (Baker and Rosenqvist, 2004). In the present study, the value of ratio of minimum fluorescence to maximum fluorescence $(\mathrm{Fo} / \mathrm{Fm})$ was found to be more in stressed plants as compared to the control plants and same in the rehydrated and control plants in both the genotypes (sensitive as well as tolerant). Many researchers (Oyetunji et al., 2007; Arji et al., 2008; Xu et al., 2008; Guerfel et al., 2009) observed that drought significantly decreased maximum efficiency of PSII $(F \mathrm{v} / F \mathrm{~m})$ and maximum effective quantum yield of PSII. We also observed that the ratio of variable fluorescence to maximum fluorescence $(\mathrm{Fv} / \mathrm{Fm})$ was lower in the stressed plants as compared to the control plants of both the genotypes, however, the decrease was more pronounced in the drought sensitive genotype. Faraloni et al., (2011) also reported that the $\mathrm{Fv} / \mathrm{Fm}$ ratio decreased by $90 \%$ in the "susceptible" cultivars of olive, whereas the "tolerant" ones did not show any decline in Fv/Fm. Sharma et al., (2012) observed that a temperature of $38^{\circ} \mathrm{C}$ with a pretreatment at $33-35^{\circ} \mathrm{C}$ was sufficient to obtain significant heat induced differences in $F \mathrm{v} / F \mathrm{~m}$ among the cultivars, which were absent in the control plants. Khaleghi et al., (2012) also reported that in young olive plants cv. Dezphul, the irrigation treatments had significant effect on chlorophyll a, total chlorophyll (chl a+b) and Fv/Fm ratio.

Differential gene expression gives rise to physiological changes. Such genes turn on/ off in response to stress. In previous reports, we have reported that hsp gene which is drought/ heat inducible is activated under drought stress in Indian mustard (Aneja et al., 2015). In the present study, we studied the induction of lhcb and $\mathrm{pp} 2 \mathrm{c}$ genes in response to drought stress in two important cultivars of Brassica juncea RH8812 (drought sensitive) and RH0116 (drought tolerant) using semiquantitative RT-PCR approach. We used actin (a constitutive or housekeeping gene) as positive control in our experiments. We found that the actin transcript was induced in roots as well as shoot tissues irrespective of the treatment, i.e. it was present in control, stressed and rehydrated plants with similar expression.

\section{Expression of pp2c in Brassica juncea under drought stress conditions}

Protein kinases and phosphatases regulate many biological processes by catalyzing phosphorylation and de-phosphorylation of proteins. Major group of protein phosphatases are monomer enzymes and represented by Type $2 \mathrm{C}$ protein phosphatases (PP2Cs) in plants. They need divalent ion $\left(\mathrm{Mg}^{2+}\right.$ or $\left.\mathrm{Mn}^{2+}\right)$ for activity and act on serine/ threonine residues, hence catagorized under protein serine/threonine phosphatases (Bhalothia et al., 2018). PP2Cs are found to be 
evolutionarily conserved from prokaryotes to eukaryotes (Sugimoto et al., 2014), found in archaea, bacteria, fungi, plants and animals (Yang et al., 2018). They negatively regulate ABA responses (Zhang et al., 2013) and MAPK cascade pathways and play crucial role in stress signal transduction in plants (Cao et al., 2016). Rodriguez (2006) suggested that if specific PP2Cs involved in ABA signaling are inactivated in combination, it could offer an approach to improve crop performance in drought.

In the present study, the expression of $p p 2 c$ gene was induced in the plants subjected to drought stress condition and not in the control and rehydrated plants. The gene was expressed in both shoots and roots of the stressed plants, however, the expression was higher in drought tolerant genotype as compared to drought sensitive genotype. This is also supported by Cohen et al., (2010) in poplar where they found that Protein phosphatase type- 2C (PP2C) was upregulated in both shoot and root tissues. Guo et al., (2009) also observed that 18 genes, including those encoding 4 l-pyrroline-5carboxylate synthetase (P5CS), protein phosphatase 2C-like protein (PP2C) were differentially expressed in all genotypes under drought in barley. Zhang et al., (2013) also supported our observation that the plant PP2CA genes appear to be expressed ubiquitously in various organs, albeit at varying levels. Wei and Si Pan (2014) reported that Group A PP2Cs were negative regulators of $\mathrm{ABA}$ signalling pathway and key regulators of drought tolerance in plants.

\section{Expression of lhcb in Brassica juncea under drought stress conditions}

The $L h c b$ gene family in green plants encodes highly homologous, conserved, numerous light-harvesting $\mathrm{Chl} a / b$-binding (LHC) proteins that harness and transfer light energy to the reaction centers of PSII (Teramoto et al., 2001). The Lhc family is bifurcated into Lhca or Lhcb depending upon whether the encoded gene product belongs to photosystem I (PSI) or photosystem II (PSII) respectively. Members of the Lhcb subfamily express differentially which plays a role in acclimating plants to excess light (Caffarri et al., 2005). The LHCB proteins are mostly complexed with chlorophyll and xanthophyll and serve as antenna complex. Xu et al., (2012) reported that the outer antenna proteins LHCBs are probably the most abundant membrane proteins. Lhcb gene expression is regulated by mainly light (Humbeck and Krupinska, 2003), chloroplast retrograde signal (Nott et al., 2006), oxidative stress and ABA (Staneloni et al., 2008). In our experiments, the expression of this gene was found to be downregulated under drought stress conditions, therefore, the transcripts were present in the control and rehydrated plants and absent in the stressed plants. However, the transcripts were present only in the shoots and not in the roots. Several studies support our findings where it has been postulated that the Lhcb genes were downregulated in stress conditions such as cold (Seki et al., 2002), high-salinity (Seki et al., 2002), drought (Hazen et al., 2005; Guo et al., 2009), exogenously applied ABA (Staneloni et al., 2008), high light (Heddad and Adamska, 2000) and infection by Puccinia triticina (Manickavelu et al., 2010). Breeze et al., (2011) also reported that LHCBs were found in the same cluster of downregulated genes together with many others encoding subunits of the PSI and PSII complexes. The pattern of the rarely expressed $L h c$ genes was always found to be more similar to that of $P s b S$ and the various light-harvesting-like genes, which might indicate distinct physiological functions for the rarely and abundantly expressed Lhc proteins. In general, Lhc genes are most strongly expressed when light harvesting is limiting 
for plant growth, i.e. in low light but otherwise optimal conditions. Since the need for efficient light harvesting is lower under high light conditions, Lhc gene expression is down regulated in strong light (Klimmek et al., 2006). Kleine et al., (2007) also found that $L h c b$ expression in the wild type was reduced to $25 \%$ of the control level after high light treatment and similarly reduced in all investigated mutants. $\mathrm{Xu}$ et al., (2012) reported that $L h c$ gene expression levels are very high in leaves but low in non green tissues, or even absent in many such tissues and in our study also, its expression was detected only in the shoots and not in the roots. The regulation of the $\angle H C B$ expression is considered to be one of the important mechanisms for plants to modulate chloroplast functions (Nott et al., 2006; De Montaigu et al., 2010; Pruneda-Paz and Kay, 2010; Thines and Harmon, 2010). The exploration of genetic variation in genes encoding LHCPs may facilitate a better understanding of functions of LHCPs and provide useful information and selection tools for plant breeders to improve plant with high photosynthesis efficiency (Xia et al., 2012).

\section{References}

Akhatar, J., Singh, M.P., Sharma, A., Kaur, H., Kaur, N., Sharma, S., Bharti, B., Sardana, V.K. and Banga, S.S. 2020. Association Mapping of Seed Quality Traits Under Varying Conditions of Nitrogen Application in Brassica juncea L. Czern \& Coss. Front. Genet. 11: 744 doi: 10.3389/fgene.2020.00744.

Alikhan, M., Ashraf, M.Y., Mujtaba, S.M., Shirazi, M.U., Khan, M.A., Shereen, A., Mumtaz, S., Siddiqui, M.A., Kaleri, G.M. 2010. Evaluation of high yielding canola type Brassica genotypes/mutants for drought tolerance using physiological indices as screening tool. Pak J Bot 42: 3807-3816.
Amudha, J. and Balasubramani, G. 2011. Recent molecular advances to combat abiotic stress tolerance in crop plants. Biotechnology and Molecular Biology Review 6(2): 31-58.

Aneja, B. 2014. Transcript profiling of stress inducible MYB transcription factor and related genes in Indian mustard (Brassica juncea L. Czern. \& Coss.), PhD Thesis, CCS Haryana Agricultural University, Hisar.

Aneja, B., Yadav, N.R., Kumar, N., Yadav, R.C. 2015. Hsp transcript induction is correlated with physiological changes under drought stress in Indian mustard. Physiol Mol Biol Plants 21(3): 305316.

Arjenaki, F.G., Jabbari, R. and Morshedi, A. 2012. Evaluation of Drought Stress on Relative Water Content, Chlorophyll Content and Mineral Elements of Wheat (Triticum aestivum L.) Varieties. International Journal of Agriculture and Crop Sciences 4(11): 726-729.

Arji, I. and Arzani, K. 2008. Effect of water stress on some biochemical changes in leaf of five olive (Olea europaea L.) cultivars. Acta Horticulturae 791: 523526.

Atia, A., Debez, A., Barhoumi, Z., Smaoui, A. and Abdelly, C. 2011. Effects of different salts and mannitol on seed imbibition, germination and ion content of Crithmum maritimum L. (Apiaceae). J. Biol. Res.-Thessalon 15: 37 - 45.

Baker, N.R. and Rosenqvist, E. 2004. Applications of chlorophyll fluorescence can improve crop production strategies: an examination of future possibilities. Journal of Experimental Botany 55: 1607-1621.

Bhalothia, P., Lata, S., Khan, Z.H., Kumar, B., Mehrotra, S. and Mehrotra, R. 2018. Genome Wide Analysis of Protein Phosphatase 2C (PP2C) Genes in Glycine $\max$ and Sorghum bicolor. 
Current Biotechnology 7(4): 302-308.

Bibi, A., Sadaqat, H.A., Akram, H.M. and Mohammed, M.I. 2010. Physiological markers for screening sorghum (Sorghum bicolor) germplasm under water stress condition. International Journal of Agricultural Biology 12: 451-455.

Breeze, E., Harrison, E., McHattie, S., Hughes, L., Hickman, R., Hill, C., Kiddle, S., Kim, Y., Penfold, C.A., Jenkins, D., Zhang, C., Morris, K., Jenner, C., Jackson, S., Thomas, B., Tabrett, A., Legaie, R., Moore, J.D., Wild, D.L., Ott, S., Rand, D., Beynon, J., Denby, K., Mead, A. and BuchananWollaston, V. 2011. High-Resolution Temporal Profiling of Transcripts during Arabidopsis Leaf Senescence Reveals a Distinct Chronology of Processes and Regulation. The Plant Cell 23: 873-894.

Caffarri, S., Frigerio, S., Olivieri1, E., Righetti, P.G. and Bassi, R. 2005. Differential accumulation of Lhcb gene products in thylakoid membranes of Zea mays plants grown under contrasting light and temperature conditions. Proteomics 5: 758-768.

Cao, J., Jiang, M., Li, P. and Chu, Z. 2016. Genome-wide identification and evolutionary analyses of the PP2C gene family with their expression profiling in response to multiple stresses in Brachypodium distachyon. BMC Genomics 17: 175.

Chaerle, L., Saibo, N. and Straeten, D.V.D. 2005. Tuning the pores: towards engineering plants for improved water use efficiency. Trends in Biotechnology 23(6): 308-315.

Chaves, M.M.; Flexas, J. and Pinheiro, C. 2009. Photosynthesis under drought and salt stress: regulation mechanisms from whole plant to cell. Annals of Botany 103(4): 551-560.
Chen, R., Ni, Z., Nie, X., Qin, Y., Dong, G., Sun, Q. 2005. Isolation and characterization of genes encoding Myb transcription factor in wheat (Triticum aestivum L.). Plant Sci 169: 1146-1154.

Chomczynski, P. 1993. A reagent for the single-step simultaneous isolation of RNA, DNA and proteins from cell and tissue samples. Biotechniques 15(3): 532-537.

Cohen, D., Bogeat-Triboulot, M-B., Tisserant, E., Balzergue, S., Martin-Magniette, ML., Lelandais, G., Ningre, N., Renou, JP., Tamby, J-P., Thiec, D.L. and Humme, I. 2010. Comparative transcriptomics of drought responses in Populus: a meta-analysis of genomewide expression profiling in mature leaves and root apices across two genotypes. BMC Genomics 11: 630.

De Montaigu, A., Tóth, R. and Coupland, G. 2010. Plant development goes like clockwork. Trends in Genetics 26(7): 296-306.

Faraloni, C.; Cutino, I.; Petruccelli, R.; Leva, A.R.; Lazzeri, S. and Torzillo, G. 2011. Chlorophyll fluorescence technique as a rapid tool for in vitro screening of olive cultivars (Olea europaea L.) tolerant to drought stress". Environmental and Experimental Botany 73: 49-56.

Gao, L. and Li, H-M. 2015. Identification of a Light-Harvesting Chlorophyll a/bBinding Protein Gene in Gardenia jasminoides. International Conference on Chemical, Material and Food Engineering (CMFE-2015) pp 142-145.

Gong, M., Van der Luit, A., Knight, M.R. and Trewavas, A.J. 1998. Heat-shock induced changes in intracellular $\mathrm{Ca}^{2+}$ level in tobacco seedlings in relation to thermotolerance. Plant Physiology 116: 429-437.

Guerfel, M., Ouni, Y., Boujnah, D. and Zarrouk, M. 2009. Photosynthesis parameters and activities of enzymes of 
oxidative stress in two young 'Chemlali' and 'Chetoui' olive trees under water deficit. Photosynthetica 47(3): 340-346.

Guo, P., Baum, M., Grando, S., Ceccarelli, S., Bai, G., Li, R., von Korff, M., Varshney, R.K., Graner, A. and Valkoun, J. 2009. Differentially expressed genes between droughttolerant and drought-sensitive barley genotypes in response to drought stress during the reproductive stage. J Exp Bot. 60(12): 3531-44.

Hatsugai, N. and Katagiri, F. 2018. Quantification of Plant Cell Death by Electrolyte Leakage Assay. Bioprotocol 8(5): e2758. DOI: 10.21769/BioProtoc. 2758.

Hayatu, M., Muhammad, S.Y. and Habibu, U. A. 2014. Effect Of Water Stress On The Leaf Relative Water Content And Yield Of Some Cowpea (Vigna unguiculata (L) Walp.) Genotype. International Journal of Scientific \& Technology Research 3(7): 148-152.

Hazen, S.P., Pathan, M.S., Sanchez, A., Baxter, I., Dunn, M. 2005. Expression profiling of rice segregating for drought tolerance QTLs using a rice genome array. Funct Integr Genomics 5: 104 116.

Heddad, M. and Adamska, I. 2000. Light stress-regulated two-helix proteins in Arabidopsis thaliana related to the chlorophyll a/b-binding gene family. Proceedings of National Academy of Sciences USA 97: 3741-3746.

Humbeck, K. and Krupinska, K. 2003. The abundance of minor chlorophyll a/bbinding proteins CP29 and LHCI of barley (Hordeum vulgare L.) during leaf senescence is controlled by light. Journal of Experimental Botany 54: 375-383.

IPCC (Intergovernmental Panel on Climate Change). 2007. Climate change impacts, adaptation and vulnerability. In summery for policymakers. IPCC working Group II: 1-22.

Kalina, D., Plich, J., Zyta, D., Sliwka, J. and Marczewski, W. 2016. The effect of drought stress on the leaf relative water content and tuber yield of a half-sib family of 'Katahdin'-derived potato cultivars. Breeding Science 66: 328331.

Khaleghi, E., Arzani, K., Moallemi, N. and Barzegar, M. 2012. Evaluation of Chlorophyll Content and Chlorophyll

Fluorescence Parameters and Relationships between Chlorophyll a, b and Chlorophyll Content Index under Water Stress in Olea europaea cv. Dezful. World Academy of Science, Engineering and Technology 68: 21122115.

Kleine, T., Kindgren, P., Benedict, C., Hendrickson, L. and Strand, A. 2007. Genome-Wide Gene Expression Analysis Reveals a Critical Role for CRYPTOCHROME1 in the Response of Arabidopsis to High Irradiance. Plant Physiology 144: 1391-1406.

Klimmek, F., Sjo din, A., Noutsos, C., Leister, D. and Jansson, S. 2006. Abundantly and Rarely Expressed Lhc Protein Genes Exhibit Distinct Regulation Patterns in Plants. Plant Physiology 140: 793-804.

Kong, F., Zhou, Y., Sun, P., Cao, M., Li, H. and Mao, Y. 2016. Identification of light-harvesting chlorophyll $a / b$-binding protein genes of Zostera marina L. and their expression under different environmental conditions. Journal of Ocean University of China 15(1): 152162.

Kumar, S., Sairam, R.K. and Prabhu, K.V. 2013. Physiological traits for high temperature stress tolerance in Brassica juncea. Indian J Plant Physiol 18(1): 89-93. 
Lin, L. Z., Sun, J., Chen, P., and Harnly, J. 2011. UHPLC-PDA-EST/HRMS/ MS $^{\mathrm{n}}$ analysis of anthocyanins, flavonol glycosides, and hydroxycinnamic acid derivatives in red mustard greens (Brassica juncea coss variety). Journal of Agricultural and Food Chemistry 59(22): 12059-12072.

Luo, Y., Zhao, X., Qu, H., Zuo, X., Wang, S., Huang, W., Luo, Y. and Chen, M. 2014. Photosynthetic performance and growth traits in Pennisetum centrasiaticum exposed to drought and rewatering under different soil nutrient regimes. Acta Physiologiae Plantarum 36: 381388.

Manickavelu, A., Kawaura, K., Oishi, K., Shin-I, T. and Kohara, Y. 2010. Comparative Gene Expression Analysis of Susceptible and Resistant NearIsogenic Lines in Common Wheat Infected by Puccinia triticina. DNA Research 17: 211-222.

Marchese, J.A., Ferreira, J.F.S., Rehder, V.L.G., Rodrigues， O. 2010. Water deficit effect on the accumulation of biomass and artemisinin in annual wormwood (Artemisia апnиa L., Asteraceae). Braz. J. Plant Physiol. 22: 1-9.

Medeiros, D., Silva, E., Santos, H., Pacheco, C., Musser, R., Nogueira, R. 2012. Physiological and biochemical responses to drought stress in Barbados cherry. Braz. J. Plant Physiol. 24(3): 181-192.

Nagaharu, U. 1935. Genome Analysis in Brassica with Special Reference to the Experimental Formation of B. Napus and Peculiar Mode of Fertilization. Japanese Journal of Botany 7: 389-452.

Nambara, E., Okamoto, M., Tatematsu, K., Yano, R., Seo, M. and Kamiya, Y. 2010. Abscisic acid and the control of seed dormancy and germination. Seed Science Research 20: 55-67.
Nilanthi, D., P.C.D., P. and Gunarathna, P. 2015. Study the Response of Drought Stress Inducing by Mannitol in Germination to Seedling Stage of Mung Bean (Vigna Radiata L.) Variety MI5 and Variety Harsha. International Journal of Scientific and Research Publications 5(7): 1-4.

Nott, A., Jung, H.S., Koussevitzky, S. and Chory, J. 2006. Plastid-to nucleus retrograde signaling. Annual Review of Plant Biology 57: 739-759.

Okçu, G., Kaya, M.D. and Atak, M. 2005. Effects of salt and drought stresses on germination and seedling growth of pea (Pisum sativum L.). Turkish Journal of Agriculture and Forestry 29: 237-242.

Oyetunji, O.J., Ekanayake, I.J. and Osonubi, O. 2007. Chlorophyll Fluorescence Analysis for Assessing Water Deficit and Arbuscular Mycorrhizal Fungi (AMF) Inoculation in Cassava (Manihot esculenta Crantz). Advances in Biological Research 1(3-4): 108-117.

Pruneda-Paz, J.L. and Kay, S.A. 2010. An expanding universe of circadian networks in high plants. Trends in Plant Sciences 15: 259-265.

Rahimi, R., Hosseini, S.M., Pooryoosef, M., Fateh, I. 2010. Variation of leaf water potential, relative water content and SPAD under gradual drought stress and stress recovery in two medicinal species of Plantago ovata and P. psyllium. Plant Ecophysiol 2: 53-60.

Rodriguez, P.L. 2006. Drought avoidance in PP2C double knock-out mutants. Plant Physiology Preview. DOI: 10.1104/pp.106.081018.

Rodziewicz, P., Swarcewicz, B., Chmielewska, K., Wojakowska, A. and Stobiecki, M. 2014. Influence of abiotic stresses on plant proteome and metabolome changes. Acta Physiol Plant 36: 1-19.

Saibo, N.J., Lourenco, T. and Oliveira, M.M. 
2009. Transcription factors and regulation of photosynthetic and related metabolism under environmental stresses. Annals of Botany 103: 609623.

Saura-Mas, S. and Lloret, F. 2007. Leaf and Shoot Water Content and Leaf Dry Matter Content of Mediterranean Woody Species with Different Post-fire Regenerative Strategies. Annals of Botany 99: 545-554.

Sayar, R., Khemira, H., Kameli, A. and Mosbahi, M. 2008. Physiological tests as predictive appreciation for drought tolerance in durum wheat (Triticum durum Desf.). Agronomy Research 6(1): 79-90.

Seki, M., Narusaka, M., Ishida, J., Nanjo, T. and Fujita, M. 2002. Monitoring the expression profiles of 7,000 Arabidopsis genes under drought, cold and high-salinity stresses using a fulllength cDNA microarray. The Plant Journal 31: 279-292.

Sharma, D.K., Andersen, S.B., Ottosen, C-O. and Rosenqvist, E. 2012. Phenotyping of wheat cultivars for heat tolerance using chlorophyll $a$ fluorescence. Functional Plant Biology http://dx.doi.org/10.1071/FP12100.

Sharma, P., Sardana, V. 2013. Screening of Indian mustard (Brassica juncea) for thermo tolerance at seedling and terminal stages. J Oilseed Brassica 4(2): $61-67$.

Silva, E.C., Silva, M.F.A., Nogueira, R.J.M.C., Albuquerque, M.B. 2010. Growth evaluation and water relations of Erythrina velutina seedlings in response to drought stress. Braz. J. Plant Physiol. 22: 225-233.

Soda, N., Wallace, S., Karan, R. 2015. Omics study for abiotic stress responses in plants. Adv Plant Agric Res 2(1): 00037.

doi:10.15406/apar.2015.02.00037
Staneloni, R.T., Rodriguez-Batiller, M.J. and Casal, J.J. 2008. Abscisic acid, highlight, and oxidative stress downregulate a photosynthetic gene via a promoter motif not involved in phytochromemediated transcriptional regulation. Molecular Plant 1: 75-83.

Street, N.R., Skogstrom, O., Tucker, J., Rodriguez-Acosta, M., Nilsson, P., Jansson, S. and Taylor, G. 2006. The genetics and genomics of the drought response in Populus. Plant Journal 48: 321-341.

Sugimoto, H., Kondo, S., Tanaka T., Imamura, C., Muramoto, N., Hattori, E., Ogawa, K., Mitsukawa, N. and Ohto, C. 2014. Journal of Experimental Botany 65(18): 5385-5400.

Teramoto, H., Ono, T. and Minagawa, J. 2001. Identification of Lhcb Gene Family Encoding the Light-harvesting Chlorophyll- $a / b$ Proteins of Photosystem II in Chlamydomonas reinhardtii Plant Cell Physiol. 42(8): 849-856.

Thines, B. and Harmon, F.G. 2010. Four easy pieces: mechanisms underlying circadian regulation of growth and development. Current Opinion in Plant Biology 14: 1-7.

Tian, Y. and Deng, F. 2020. Phytochemistry and biological activity of mustard (Brassica juncea): a review. CytaJournal of Food 18(1): 704-718.

Ullah, I., Akhtar, N., Mehmood, N., Shah, I.A. and Noor, M. 2014. Effect of mannitol induced drought stress on seedling traits and protein profile of two wheat cultivars. J. Anim. Plant Sci. 24(4): 1246-1251.

Wei, K. and Pan, S. 2014. Maize protein phosphatase gene family: identification and molecular characterization. BMC Genomics 15:773.

Wilson, R.A., Sangha, M.K., Banga, S.S., Atwal, A.K. and Gupta, S. 2014. Heat 
stress tolerance in relation to oxidative stress and antioxidants in Brassica juncea. J Environ Biol 35: 383-387.

Xia, Y., Ning, Z., Bai, G., Li, R., Yan, G. et al. 2012. Allelic Variations of a Light Harvesting Chlorophyll A/B-Binding Protein Gene (Lhcbl) Associated with Agronomic Traits in Barley. PLoS ONE 7(5): e37573. doi:10.1371/journal.pone.0037573

Xu, X., Peng, G., Wu, C., Korpelainen, H., Li, C. 2008. Drought inhibits photosynthetic capacity more in females than in males of Populus cathayana. Tree Physiol 28: 1751-1759.

Xu, Y.H.; Liu, R.; Yan, L.; Liu, Z-Q.; Jiang, S-C.; Shen, Y-Y.; Wang, X-F. and Zhang, D-P. 2012. Light-harvesting chlorophyll $a / b$-binding proteins are required for stomatal response to abscisic acid in Arabidopsis. Journal of Experimental Botany 63(3): 1095-1106.

Yamasaki, S., Dillenburg, L.R. 1999. Measurements of leaf relative water content in Araucaria angustifolia. Rev Bras de Fisiol Veg 11(2): 69-75.

Yan, A., Wu, M., Yan, L., Hu, R., Ali, I. and Gan, Y. 2014. AtEXP2 Is Involved in Seed Germination and Abiotic Stress Response in Arabidopsis. PLoS One 9(1): https://doi.org/10.1371/journal.pone.008 5208

Yang, Q., Liu, K., Niu, X. et al. 2018. Genome-wide Identification of $P P 2 C$ Genes and Their Expression Profiling in Response to Drought and Cold Stresses in Medicago truncatula. Sci Rep 8: 12841.

Yang, Q., Liu, K., Niu, X., Wang, Q., Wan, Y., Yang, F., Li, G., Wang, Y. and Wang, R. 2018. Genome-wide Identification of PP2C Genes and Their Expression Profiling in Response to Drought and Cold Stresses in Medicago truncatula. Sci Rep. 8(1): 12841. doi: 10.1038/s41598-018-29627-9.

Zhang, J., Li, X., He, Z., Zhao, X., Wang, Q., Zhou, B., Yu, D., Huang, X., Tang, D., Guo, X. and Liu, X. 2013. Molecular character of a phosphatase 2C (PP2C) gene relation to stress tolerance in Arabidopsis thaliana. Molecular Biology Reports 40: 2633-2644.

Zhang, X., Wollenweber, B., Jiang, D., Liu, F. and Zhao, J. 2008. Water deficits and heat shock effects on photosynthesis of a transgenic Arabidopsis constitutively expressing ABP9, a ZIP transcription factor. Journal of Experimental Botany 59(4): 839-848.

\section{How to cite this article:}

Bharti Aneja, Vishal Sharma, Neelam R. Yadav, Ram C. Yadav and Dudeja, S. S. 2021. Effect of Drought Stress on Photosynthetic Parameters and Gene Expression in Brassica juncea L. (Czern. and Coss.). Int.J.Curr.Microbiol.App.Sci. 10(02): 550-570. doi: https://doi.org/10.20546/ijcmas.2021.1002.066 